\title{
Changes of Visual Evoked Potentials in Patients with Thyroid Dysfunction
}

\author{
CITTO IULIAN TAISESCU1*, VIOREL BICIUSCA ${ }^{2}$, LORENA SAS ${ }^{3}$, GEORGIANA CAMEN ${ }^{4}$, TEODOR SAS 4 , CARMEN ALBU 5 , \\ OANA TAISESCU ${ }^{3}$ \\ 'University of Medicine and Pharmacy of Craiova, Department of Physiology, 2 Petru Rares, 200349,Craiova, Romania \\ 2University of Medicine and Pharmacy of Craiova, Department of Semiology, 2 Petru Rares, 200349, Craiova, Romania \\ 3University of Medicine and Pharmacy of Craiova, Department of Anatomy, 2 Petru Rares, 200349, Craiova, Romania \\ 4University of Medicine and Pharmacy of Craiova, Department of Radiology, 2 Petru Rares, 200349, Craiova, Romania \\ EUniversity of Medicine and Pharmacy of Craiova,Department of Neurology, 2 Petru Rares, 200349, Craiova, Romania
}

The visual evoked potentials technique records the cerebral bioelectric activity generated by lightstimulation. Evoked potentials is a good method of assessing the electrical response of the brain to different stimuli and has been used extensively in the study of brain disturbances. We registered VEP on 18 hyperthyroid and 18 hypothyroid patients, without other endocrine, metabolic, ophthalmologic or neurological illnesses, the 2 groups having practically identical ages, but sex repartition, illness age and treatment duration being statistically different $(p<0.001)$. Hormonal, radiological, biochemical dosages and physiological paraclinic determinations were performed on all 36 subjects, through classical methods, and VEP recordings, with a 4channel polygraph through pattern reversal stimulation (1 Hz), measuring all parameters (latency, amplitude, duration, surface, steepness etc.) of N75 and P100 waves. Between groups, the recorded hormone levels and other recordings showed great differences, very highly statistically significant $(p<0.001)$, only arterial pressures being just statistically significant $(p<0.05)$. The Pearson's $r$ correlation coefficients indicated extremely high correlations ( $r=0.90-0.98)$ between all parameters. Between the 2 groups, hypothyroid patients had latencies of $P 100$ wave higher with $17.88 \%(p=0.0028)$ and of the N75 wave with $9.98 \%$ $(p=0.016)$, and the duration of the N75 wave lower with $26.37 \%(p=0.026)$, the other parameters of VEP waves modifying up to $52.35 \%$, not statistically sgnificant due to high standard deviations. The duration of $N 75$ correlates with the majority of humoral-paraclinical parameters, indicating a functional interdependency between them and the function of the cortex. The ratio of the amplitudes and of the areas of P100/N75 indicate a severe inhibition to hypothyroid patients, a precisely quantified reduction of the cerebral activity.

Keywords: hyperthyroidism, hypothyroidism, visual evoked potentials (VEP)

Evoked potentials can be defined as voltage variations that can be recorded at the level of some components of the nervous system in response to different sensory stimulation modalities [2-4]. The visual evoked potentials technique records the cerebral bioelectric activity generated by light stimulation [5, 7-9]. Visual evoked potentials is a electrophysiological test $[10,11]$, a good method of assessing the electrical response of the brain to visual stimuli for evaluation of impulse travel from the eye to the occipital cortex [40].

Thyroid hormone are involved in myelin production, axonal transportation, and neurotransmission [13-15]. Variations in thyroid hormone concentrations may cause abnormalities in the perception and conduction of impulses from the receptor level to the occipital cortex[35].

We studied the visual evoked potentials in 18 patients with hyperthyroidism and 18 patients with hypothyroidism, also, we compared hyperthyroid patients with hypothyroid patients $[17,18]$ and we studied not only the P100 wave and the N75 wave latencies, but also all of their 7 parameters.

\section{Experimental part}

Materials and methods

This study was conducted in the period 2014-2017, through the collaboration between the Department of Physiology of UMF Craiova and the Department of Internal Medicine of Emergency Military Clinic Hospital Stefan Odobleja, from Craiova. Thirty-six patients with thyroid disease were investigated by the visual evoked potential, which of 18 patients with hypothyroidism and 18 patients with hyperthyroidism. The subjects presented an obvious thyroid pathology, diagnosed based on clinical manifestations and paraclinical determinations $[6,19,20]$. All patients had evidence of medium-intensity thyroid disease without complications of cardiovascular, ophthalmological, psychiatric or hematological nature [12, 16]. It is known that antithyroid drugs have been associated with development of agranulocytosis or secondary autoimmune neutropenia [1]. The questionable cases, with early-stage disease with unsafe diagnostics, with manifestations at the limit, have been removed. Records were made on each subject once, as soon as possible after hospital admission, 1-2 days after treatment commenced. The recording conditions have always been the same of thermal comfort, semi-security, lack of noise and mental relaxation [22, 23].

The modifications of visual evoked potentials (VEP) were determined by recordings of these potentials in parallel with the hormonal, biochemical and physiological manifestations (pressure, reflexes) $[25,26]$, on a total number of 36 patients with thyroid pathology, 18 with hyperthyroid and 18 with hypothyroid. The male gender predominated with 27 cases (75\%). The predominance of the male gender was even higher on the hyperthyroid lot (16 cases, that is $88.89 \%$ ), being lower at hypothyroid (11 cases- $61.11 \%$ ) (table 1 ).

The sanguine concentration of the T3 and T4 hormones were dosed using classic methods [28, 33]. Lipemia and cholesterolemia were determined with the help of classical 


\begin{tabular}{|c|c|c|c|c|c|c|}
\hline & $\begin{array}{c}\text { Hyperthyroid } \\
\text { Patients } \\
\text { Absolute } \\
\text { values }\end{array}$ & $\begin{array}{c}\text { Hyperthyroid } \\
\text { Patients } \\
\text { Relative } \\
\text { values }\end{array}$ & $\begin{array}{c}\text { Hypothyroid } \\
\text { Patients } \\
\text { Absolute } \\
\text { values }\end{array}$ & $\begin{array}{c}\text { Hypothyroid } \\
\text { Patients } \\
\text { Relative } \\
\text { values }\end{array}$ & $\begin{array}{c}\text { Total } \\
\text { absolute } \\
\text { values }\end{array}$ & $\begin{array}{c}\text { Total } \\
\text { relative } \\
\text { values }\end{array}$ \\
\hline Men & 16 & $88.89 \%$ & 11 & $61.11 \%$ & 27 & $75.00 \%$ \\
\hline Women & 2 & $11.11 \%$ & 7 & $38.89 \%$ & 9 & $25.00 \%$ \\
\hline Total & 18 & $100.00 \%$ & 18 & $100.00 \%$ & 36 & $100.00 \%$ \\
\hline
\end{tabular}

Table 1

SEX REPARTITION OF HYPERTHYROID AND HYPOTHYROID PATIENTS. ABSOLUTE VALUES AND THEN RELATIVE VALUES (\%) biochemical analysis, on blood collected a jeune, under identical conditions for all subjects and at the same time of the day. The basal metabolism was determined under rigorously kept basic conditions, through a modern device $[30,39]$. The Achilean reflexogram was recorded with an efficient dedicated electronic device, and by classic clinical methods the cardiac frequency and the minimum and maximum blood pressure were measured, in a state of basal rest, at the same time of the day.

The subject is in absolute physical and psychical rest, in a dusky room, free of noise, in thermal balance, with no hunger, third, warm-cold, pain (head ache, arthralgia) sensations, with no thyroid medication for 6 days, with no exciting, depressing substances (coffee etc.), tranquillizers, neurotropic vitamins [32, 36], the subject sitting comfortably on a chair and looking attentively at the screen through which the repeated photic stimuli are applied. If the subject has refraction vices, he will look through the vice-correcting glasses.

Placing of the EEG electrodeswas performed according to figure 1 , after degreasing the skin and applying electroconductive paste, the electrodes being fixed by collodion

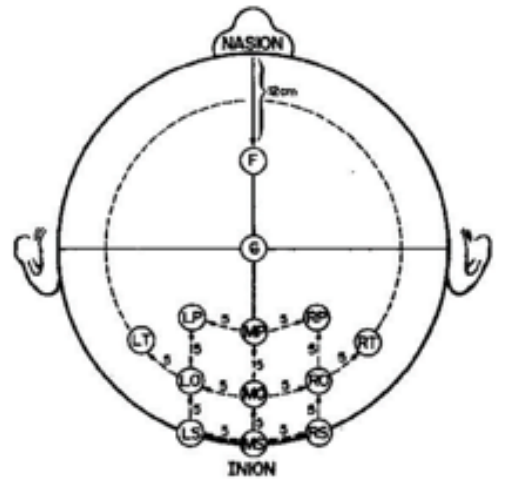

Fig.1. The classic diagram for placing of the electrodes on the scalp gluing (fig.1). We used a Nihon-Kohden Neuropack M1 with Neurofax module.

In order to extract VEP signals from the EEGs, we recorded $300 \mathrm{~ms}$ after applying the photic excitation. The sampling frequency was $1000 \mathrm{~Hz}$ (therefore one sample/ $\mathrm{ms})$, and the analog-digital conversion (A/D) was done on 12 bits.

Normally 100-180 answers were summed. In order to precisely identify the level of the isoelectric line, we started adding the samples with $60 \mathrm{~ms}$ before the moment of applying the photic excitation technique. Therefore at each addition 360 samples were added, 60 before, 300 after the stimulation.

Of all the differenttechniques used for photic stimulation (flash, rotating mirror projector, TV screen, LED screen etc.), the on screen LED stimulation is the best, precise and physiological ( 2 and 5 ). The pattern reversal stimulation method was used, with the help of a matrix of approximately $10 \times 15 \mathrm{~cm}$, made from a few thousand yellow-green LEDs, . The photic stimulation frequency was of $1 \mathrm{~Hz}$ the highest.

\section{Results and discutions}

The average ages of the two groups were a little different, $40.89+1-6.02$ in hyperthyroid, with limits between 30 and 50 years and $38.22+/-11.08$ in hypothyroids, with limits between 22 and 50 years (table 2).

The age of the illness in studied hyperthyroid was 2.33 years $+/-1.97$, and the duration of the treatment $1.22+/$ 1.77 years, and in hypothyroid the age was $6.06+/-3.10$ years and the duration of the treatment $5.36+/-3.6$ years (table 2).

\begin{tabular}{|c|c|c|c|c|c|c|}
\hline & \multicolumn{3}{|c|}{ Hyperthyroid Patients } & \multicolumn{3}{c|}{ Hypothyroid Patients } \\
\hline & Age & IIIness & Treatment & Age & Illness & Treatment \\
\hline Average & 40.89 & 2.33 & 1.22 & 39.22 & 6.06 & 5.36 \\
\hline Standard Deviation & 6.02 & 1.97 & 1.77 & 11.08 & 3.10 & 3.60 \\
\hline CV & 14.72 & 84.44 & 145.43 & 28.25 & 51.13 & 67.24 \\
\hline Standard Error & 1.42 & 0.46 & 0.42 & 2.61 & 0.73 & 0.85 \\
\hline Median & 40.50 & 2.00 & 0.79 & 45.50 & 6.00 & 5.50 \\
\hline Min & 30.00 & 1.00 & 0.08 & 22.00 & 2.00 & 0.50 \\
\hline Max & 50.00 & 10.00 & 8.00 & 50.00 & 15.00 & 15.00 \\
\hline Confidence interval - & 37.90 & 1.35 & 0.34 & 33.71 & 4.52 & 3.57 \\
\hline Confidence interval + & 43.88 & 3.31 & 2.10 & 44.73 & 7.60 & 7.15 \\
\hline Skewness & -0.59 & 15.66 & 14.54 & -1.59 & 3.04 & 1.68 \\
\hline Kurtosis & -0.27 & 3.84 & 3.68 & -0.55 & 1.36 & 0.96 \\
\hline
\end{tabular}

Table 2

STATISTICAL PROCESSING OF AGE, ILLNESS DURATION AND TREATMENT DURATION FOR HYPERTHYROID PATIENTS AND HYPOTHYROID PATIENTS

Table 3

STATISTICAL ENSURING OF ABSOLUTE AND RELATIVE (\%) DIFFERENCES BETWEEN HYPOTHYROID PATIENTS AND HYPERTHYROID PATIENTS (CONSIDERED 100\%) FOR AGE, ILLNESS DURATION, TREATMENT DURATION

\begin{tabular}{|c|c|c|c|c|c|c|c|c|}
\hline \multicolumn{3}{|c|}{ Absolute difference } & \multicolumn{3}{|c|}{$\begin{array}{c}\text { Relative difference } \\
\text { for Hyperthyroid } \\
\text { Patients }\end{array}$} & \multicolumn{3}{|c|}{$\begin{array}{c}\text { Statistical ensure } \\
\text { of lot differences } \\
\text { expressed through p value }\end{array}$} \\
\hline Age & Illness & Treatment & Age & Illness & Treatment & Age & Illness & Treatment \\
\hline 1.67 & -3.72 & -4.14 & 4.07 & -159.52 & -340.63 & 0.58736 & 0.00050 & 0.00042 \\
\hline
\end{tabular}


The average ages of the two groups (with very close values) was not statistically significant, (Student t test $p>0.05$ ), while statistic differences between the average age of the illness and the average duration of the treatment were highly significant ( $p=0.0005$, and 0.0004 respectively) (table 3).

Obtained hormonal, iodine uptake, biochemical, metabolism, reflectivity and cardiovascular values. Tables $4,5,6,7,8$ present the average values, standard deviations, the coefficient of variation \% (CV\%) and other current statistic parameters for all the performed determinations, the absolute and relative differences (\%) between the averages of the two studies groups and the statistic insurances of these differences, and in figure 2, 3, and 4 the important data in the quoted tables is exposed graphically in absolute values then percents [21, 27, 31], hypothyroid as opposed to hyperthyroid considered comparison standard (100\%).

In tables 4 and 5 great differences can be observed (complying with familiar clinical and paraclinical semiology) between the average values of hyper and hypothyroids.

Then itcan also be observed that the majority of obtained mediums have a very high safety and informative value, CV\% being below $10 \%$ (see yellow colored boxes), and the ones with CV\% over $10 \%$ have $11,15,16$, maximum $21 \%$,

Table 4

STATISTICAL PROCESSING OF HORMONAL, BIOCHEMICAL, PARACLINICAL AND PHYSIOLOGICAL VALUES FOR HYPERTHYROID PATIENTS. YELLOW-ORANGE COLORED BOXES INDICATE THAT THE AVERAGE VALUE HAS A LOW STANDARD DEVIATION AND IMPLICITELY A LOW \% COEFFICIENT OF VARIATION, BELOW $10 \%$.

\begin{tabular}{|c|c|c|c|c|c|c|c|c|c|c|c|}
\hline $\begin{array}{l}\text { Hyperthyr } \\
\text { oid } \\
\text { Patients }\end{array}$ & $\begin{array}{l}\mathrm{T} 4 \\
\text { (mg/d } \\
\text { I) }\end{array}$ & $\begin{array}{l}\mathrm{T} 3 \\
\text { (mg/d } \\
\text { I) }\end{array}$ & $\begin{array}{l}\mathrm{RIC} \\
2 \mathrm{~h}\end{array}$ & $\begin{array}{l}\text { RIC } \\
24 \mathrm{~h}\end{array}$ & $\begin{array}{l}\text { Lipemi } \\
\text { a } \\
(\mathrm{mg} \%)\end{array}$ & $\begin{array}{l}\text { Cholester } \\
\text { ol } \\
(\mathrm{mg} \%)\end{array}$ & $\begin{array}{l}\text { Basal } \\
\text { metab.( } \\
\%)\end{array}$ & $\begin{array}{l}\text { Achilles } \\
\text { Reflex } \\
\text { (ms) }\end{array}$ & $\begin{array}{l}\text { Cardiac } \\
\text { Freq.(bp } \\
\text { m) }\end{array}$ & $\begin{array}{l}\text { MAX } \\
\text { BP } \\
\text { (mmH } \\
\text { g) }\end{array}$ & $\begin{array}{l}\text { MIN } \\
\text { BP } \\
\text { (mmH } \\
\text { g) }\end{array}$ \\
\hline Average & 18.72 & $\begin{array}{l}254.2 \\
2 \\
\end{array}$ & 0.27 & 0.40 & $\begin{array}{l}669.5 \\
6 \\
\end{array}$ & 179.50 & 0.35 & 258.17 & 103.94 & 146.67 & 63.89 \\
\hline $\begin{array}{l}\text { Standard } \\
\text { Deviation }\end{array}$ & 3.61 & 22.45 & 0.03 & 0.04 & 46.33 & 27.91 & 0.03 & 10.52 & 6.96 & 9.55 & 4.04 \\
\hline CV $(\%)$ & 19.28 & 8.83 & $\begin{array}{l}11.0 \\
0 \\
\end{array}$ & $\begin{array}{l}10.4 \\
6 \\
\end{array}$ & 6.92 & 15.55 & 7.76 & 4.08 & 6.69 & 6.51 & 6.33 \\
\hline $\begin{array}{l}\text { Standard } \\
\text { Error }\end{array}$ & 0.85 & 5.29 & 0.01 & 0.01 & 10.92 & 6.58 & 0.01 & 2.48 & 1.64 & 2.25 & 0.95 \\
\hline Median & 18.00 & $\begin{array}{l}249.0 \\
0\end{array}$ & 0.26 & 0.40 & $\begin{array}{l}665.0 \\
0 \\
\end{array}$ & 172.50 & 0.36 & 258.00 & 101.00 & 145.00 & 65.00 \\
\hline Min & 14.00 & $\begin{array}{l}231.0 \\
0\end{array}$ & 0.23 & 0.35 & $\begin{array}{l}580.0 \\
0\end{array}$ & 145.00 & 0.30 & 240.00 & 92.00 & 130.00 & 60.00 \\
\hline Max & 27.00 & $\begin{array}{l}301.0 \\
0\end{array}$ & 0.32 & 0.48 & $\begin{array}{l}742.0 \\
0 \\
\end{array}$ & 215.00 & 0.40 & 272.00 & 120.00 & 165.00 & 70.00 \\
\hline $\begin{array}{l}\text { Confidenc } \\
\text { e interval - }\end{array}$ & 17.05 & $\begin{array}{l}243.8 \\
5\end{array}$ & 0.25 & 0.38 & $\begin{array}{l}648.1 \\
5\end{array}$ & 166.61 & 0.34 & 253.31 & 100.73 & 142.26 & 62.02 \\
\hline $\begin{array}{c}\text { Confidenc } \\
\text { e interval } \\
+ \\
\end{array}$ & 20.39 & $\begin{array}{l}264.6 \\
0 \\
\end{array}$ & 0.28 & 0.42 & $\begin{array}{l}690.9 \\
6 \\
\end{array}$ & 192.39 & 0.36 & 263.03 & 107.16 & 151.08 & 65.76 \\
\hline Skewness & 0.23 & 0.71 & $\overline{0} .59$ & $\overline{0} .08$ & -0.22 & -1.89 & -0.41 & -1.15 & 0.06 & 0.06 & -1.28 \\
\hline Kurtosis & 0.93 & 1.30 & 0.72 & 0.84 & -0.12 & 0.19 & -0.24 & -0.27 & 0.55 & 0.54 & 0.45 \\
\hline
\end{tabular}

Table 5

STATISTICAL PROCESSING OF HORMONAL, BIOCHEMICAL, PARACLINICAL AND PHYSIOLOGICAL VALUES FOR HYPERTHYROID PATIENTS YELLOW -ORANGE COLORED BOXES INDICATE THAT THE AVERAGE VALUE HAS A LOW STANDARD DEVIATION AND IMPLICITELY A LOW \% COEFFICIENT OF VARIATION, BELOW 10\%

\begin{tabular}{|c|c|c|c|c|c|c|c|c|c|c|c|}
\hline $\begin{array}{l}\text { Hypothyro } \\
\text { id } \\
\text { Patients }\end{array}$ & $\begin{array}{l}\mathrm{T} 4 \\
\text { (mg/d } \\
\text { I) }\end{array}$ & $\begin{array}{l}\mathrm{T} 3 \\
\text { (mg/d } \\
\text { I) }\end{array}$ & $\begin{array}{l}\text { RIC } \\
2 h\end{array}$ & $\begin{array}{l}\text { RIC } \\
24 h\end{array}$ & $\begin{array}{l}\text { Lipemi } \\
\text { a } \\
(\mathrm{mg} \%)\end{array}$ & $\begin{array}{l}\text { Cholester } \\
\text { ol } \\
(\mathrm{mg} \%)\end{array}$ & $\begin{array}{l}\text { Basal } \\
\text { metab.( } \\
\%)\end{array}$ & $\begin{array}{l}\text { Achilles } \\
\text { Reflex } \\
\text { (ms) }\end{array}$ & $\begin{array}{l}\text { Cardiac } \\
\text { Freq.(bp } \\
\text { m) }\end{array}$ & $\begin{array}{l}\text { MAX } \\
\text { BP } \\
\text { (mmH } \\
\text { g) }\end{array}$ & $\begin{array}{l}\text { MIN } \\
\text { BP } \\
\text { (mmH } \\
\text { g) }\end{array}$ \\
\hline Average & 3.07 & 51.22 & 0.11 & 0.21 & $\begin{array}{l}919.9 \\
4\end{array}$ & 343.17 & -0.14 & 361.28 & 70.61 & 137.22 & 72.78 \\
\hline $\begin{array}{l}\text { Standard } \\
\text { Deviation }\end{array}$ & 0.49 & 8.31 & 0.01 & 0.01 & 61.90 & 39.57 & 0.03 & 6.89 & 4.07 & 15.74 & 10.46 \\
\hline $\mathrm{CV}(\%)$ & 15.97 & 16.22 & $\begin{array}{l}11.7 \\
2 \\
\end{array}$ & 7.04 & 6.73 & 11.53 & -21.87 & 1.91 & 5.77 & 11.47 & 14.38 \\
\hline $\begin{array}{l}\text { Standard } \\
\text { Error }\end{array}$ & 0.12 & 1.96 & 0.00 & 0.00 & 14.59 & 9.33 & 0.01 & 1.62 & 0.96 & 3.71 & 2.47 \\
\hline Median & 3.05 & 54.00 & 0.11 & 0.20 & $\begin{array}{l}912.0 \\
0\end{array}$ & 354.00 & -0.15 & 360.50 & 71.00 & 137.50 & 72.50 \\
\hline Min & 2.30 & 38.00 & 0.08 & 0.18 & $\begin{array}{l}810.0 \\
0 \\
\end{array}$ & 270.00 & -0.20 & 350.00 & 58.00 & 120.00 & 60.00 \\
\hline Max & 4.00 & 62.00 & 0.12 & 0.23 & $\begin{array}{l}992.0 \\
0\end{array}$ & 410.00 & -0.09 & 374.00 & 75.00 & 165.00 & 85.00 \\
\hline $\begin{array}{c}\text { Confidenc } \\
\text { e interval } \\
-\end{array}$ & 2.84 & 47.38 & 0.10 & 0.20 & $\begin{array}{l}891.3 \\
5\end{array}$ & 324.89 & -0.16 & 358.09 & 68.73 & 129.95 & 67.94 \\
\hline $\begin{array}{c}\text { Confidenc } \\
\text { e interval } \\
+ \\
\end{array}$ & 3.29 & 55.06 & 0.11 & 0.21 & $\begin{array}{l}948.5 \\
4 \\
\end{array}$ & 361.45 & -0.13 & 364.46 & 72.49 & 144.49 & 77.61 \\
\hline Skewness & -0.30 & -1.36 & $\overline{0} .65$ & $\overline{0} .35$ & -1.23 & -0.18 & -0.73 & -0.86 & 4.55 & -1.22 & -1.79 \\
\hline Kurtosis & 0.14 & -0.41 & $\overline{0} \bar{s}$ & $\overline{0.11}$ & -0.26 & -0.38 & 0.37 & 0.09 & -1.73 & 0.40 & -0.07 \\
\hline
\end{tabular}


so not very high. Thus all the obtained mediums, generally speaking, are safe from an informative statistic point of view $[24,29]$.

The differences between the average values obtained on the lot of hyperthyroid patients compared to the ones obtained on the lot of hypothyroid patients $[37,41]$ are very high, between $32.02 \%$ and $140.85 \%$ - the majority are
$40 \pm 91 \%$ at nine comparisons, only at 2 they are lower than $13.91 \%$ and 6.44 (table 6).

There are significant statistical ensurances between the two lots for all the parameters.

These great differences are statistically significant [34, $38]$, with very high significance $(p<0.001)$ in most cases, as shown by 3 calculus methods (Student, ANOVA, Chi²),

Table 6

AVERAGE ABSOLUTE VALUES OF HORMONAL, BIOCHEMICAL, PARA-CLINICAL, AND PHYSIOLOGICAL DETERMINATIONS FOR HYPERTHYROID PATIENTS AND HYPOTHYROID PATIENTS, ABSOLUTE AND RELATIVE DIFFERENCES FOR THE VALUES BETWEEN THE TWO LOTS AND STATISTICAL PROOFING OF THESE DIFFERENCES

\begin{tabular}{|c|c|c|c|c|c|c|c|c|c|c|c|}
\hline Parameter & $\begin{array}{l}\text { T4 } \\
(\mathrm{mg} / \mathrm{dl})\end{array}$ & $\begin{array}{l}\text { T3 } \\
(\mathrm{mg} / \mathrm{dl})\end{array}$ & $\begin{array}{l}\text { RIC } \\
2 \mathrm{~h}\end{array}$ & $\begin{array}{l}\text { RIC } \\
24 h\end{array}$ & $\begin{array}{l}\text { Lipemia } \\
\text { (mg\%) }\end{array}$ & $\begin{array}{l}\text { Chol. } \\
\text { (mg\%) }\end{array}$ & $\begin{array}{l}\text { Basal } \\
\text { metab. } \\
(\%)\end{array}$ & $\begin{array}{l}\text { Achilles } \\
\text { Reflex } \\
\text { (ms) }\end{array}$ & $\begin{array}{l}\text { Cardiac } \\
\text { Freq. } \\
\text { (bpm) }\end{array}$ & $\begin{array}{l}\text { MAX BP } \\
(\mathrm{mmHg})\end{array}$ & $\begin{array}{l}\text { MIN BP } \\
(\mathrm{mmHg})\end{array}$ \\
\hline $\begin{array}{l}\text { Abs. Value } \\
\text { for Hyperth. } \\
\text { Patients }\end{array}$ & 18.72 & 254.22 & 27.00 & 40.00 & 669.56 & 179.50 & 35.00 & 258.17 & 103.94 & 146.67 & 63.89 \\
\hline $\begin{array}{l}\text { Abs. Value } \\
\text { for Hypoth. } \\
\text { Patients }\end{array}$ & 3.07 & 51.22 & 11.00 & 21.00 & 919.94 & 343.17 & -14.00 & 361.28 & 70.61 & 137.22 & 72.78 \\
\hline $\begin{array}{l}\text { Absolute } \\
\text { difference. }\end{array}$ & 15.66 & 203.00 & 0.16 & 0.20 & -250.39 & -163.67 & 0.50 & -103.11 & 33.33 & 9.44 & -8.89 \\
\hline $\begin{array}{l}\text { Difference } \\
\%\end{array}$ & 83.62 & 79.85 & 59.33 & 48.62 & -37.40 & -91.18 & 140.85 & -39.94 & 32.07 & 6.44 & -13.91 \\
\hline $\begin{array}{l}\text { Statistical } \\
\text { proofing } \\
\text { through } \\
\text { Student test }\end{array}$ & $1.30 * 10^{-12}$ & $5.17^{*} 10^{-47}$ & $1.56 * 10^{-12}$ & $3.72 * 10^{-12}$ & $321 * 10^{-12}$ & $7.82 * 10^{-11}$ & $6.62 * 10^{-20}$ & $6.80^{\circ} 10^{-17}$ & $5.8 * 10^{-11}$ & 0.02132 & 0.00226 \\
\hline
\end{tabular}

\begin{tabular}{|l|l|l|l|l|l|l|}
\hline \multicolumn{1}{|c|}{ PARAMETERS } & Student & & ANOVA & & $\mathrm{CH}^{2}$ & \\
\hline T4 & $1.30^{*} 10^{-12}$ & VHS & 0.0001 & VHS & 0.034 & S \\
\hline T3 & $5.17^{*} 10^{-17}$ & VHS & 0.0000 & VHS & 0.035 & S \\
\hline RIC2 & $1.56 * 10^{-12}$ & VHS & 0.0000 & VHS & 0.032 & S \\
\hline RIC24 & $3.72 * 10^{-13}$ & VHS & 0.0001 & VHS & 0.028 & S \\
\hline LIPEMIA & $3.21^{*} 10^{-12}$ & VHS & 0.0002 & VHS & 0.034 & S \\
\hline CHOLESTEROL & $7.82^{*} 10^{-11}$ & VHS & 0.0002 & VHS & 0.034 & S \\
\hline BASAL METAB. & $6.62^{*} 10^{-20}$ & VHS & 0.0000 & VHS & 0.033 & S \\
\hline ACH. REFLEX & $6.86^{*} 10^{-17}$ & VHS & 0.0000 & VHS & 0.034 & S \\
\hline CARD. FREQ. & $5.8^{*} 10^{-11}$ & VHS & 0.0000 & VHS & 0.034 & S \\
\hline MAX BP & 0.02132 & S & - & & 85 & NS \\
\hline MIN BP & 0.00226 & HS & 0.0001 & VHS & 0.4 & S \\
\hline
\end{tabular}

\section{Table 7}

STATISTICAL ENSURING THROUGH STUDENT, ANOVA AND CHI SQUARE TESTS OF THE DIFFERENCES BETWEEN THE TWO LOTS OF THYROID PATIENTS (BETWEEN THE AVERAGE VALUES OF HORMONAL, BIOCHEMICAL, PARACLINICAL, AND PHYSIOLOGICAL DETERMINATIONS). THERE ARE VERY HIGH STATISTICAL ENSURANCES (VHS) FOR MOST OF THE PARAMETERS

PERCENTAGE FORMULATION OF THE DIFFERENCES BETWEEN THE 2 LOTS OF THE AVERAGE VALUES OF ALL PREVIOUSLY SPECIFIED DETERMINATIONS. THE DIFFERENCES BETWEEN THE AVERAGE VALUES OF THE TWO LOTS ARE STATISTICAL ENSURED WITH VERY HIGH SIGNIFICANCE (VHS)

\begin{tabular}{|l|l|l|l|l|l|l|l|l|l|l|l|}
\hline & $\begin{array}{l}\text { T4 } \\
(\mathrm{mg} / \mathrm{dl})\end{array}$ & $\begin{array}{l}\text { T3 } \\
(\mathrm{mg} / \mathrm{dl})\end{array}$ & $\begin{array}{l}\text { RIC } \\
2 \mathrm{~h}\end{array}$ & $\begin{array}{l}\text { RIC } \\
24 \mathrm{~h}\end{array}$ & $\begin{array}{l}\text { Lipemia } \\
(\mathrm{mg} \%)\end{array}$ & $\begin{array}{l}\text { Cholesterol } \\
(\mathrm{mg} \%)\end{array}$ & $\begin{array}{l}\text { Basal } \\
\text { metab.(\%) }\end{array}$ & $\begin{array}{l}\text { Achilles } \\
\text { Reflex (ms) }\end{array}$ & $\begin{array}{l}\text { Cardiac } \\
\text { Freq.(bpm) }\end{array}$ & $\begin{array}{l}\text { MAX BP } \\
(\mathrm{mmH})\end{array}$ & $\begin{array}{l}\text { MIN BP } \\
(\mathrm{mmH})\end{array}$ \\
\hline HIPER & 100 & 100 & 100 & 100 & 100 & 100 & 100 & 100 & 100 \\
\hline HIPO & 16.38 & 20.15 & 40.67 & 51.38 & 137.40 & 191.18 & -40.85 & 139.94 & 67.93 & 93.56 & 113.91 \\
\hline p Student= & $1.3 \mathrm{E}-12$ & $5.17 \mathrm{E}-17$ & $1.56 \mathrm{E}-12$ & $3.72 \mathrm{E}-13$ & $3.21 \mathrm{E}-12$ & $7.82 \mathrm{E}-11$ & $6.62 \mathrm{E}-20$ & $6.86 \mathrm{E}-17$ & $5.8 \mathrm{E}-11$ & 0.02132 & 0.00226 \\
\hline
\end{tabular}

Absolute average values for hormonal, biochemical and paraclinical determinations for thyroid patients and statistical ensurance ๑HYPER aHYPO

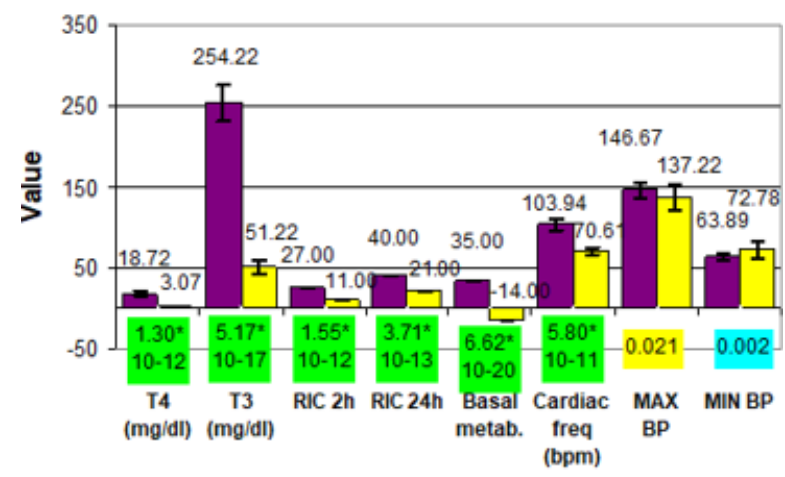

Fig.2. Above the superior part of any column is the absolute numerical value of the parameter. The small horizontal rectangles, colored green, blue or yellow, placed below the abscise expose the $p$ values obtained through Student's $t$ test, respectively how large the statistical ensurance of differences between the 2 patient lots is 
Absolute average values for biochemical and physiological determinations on thy roid patients and statistical ensurance

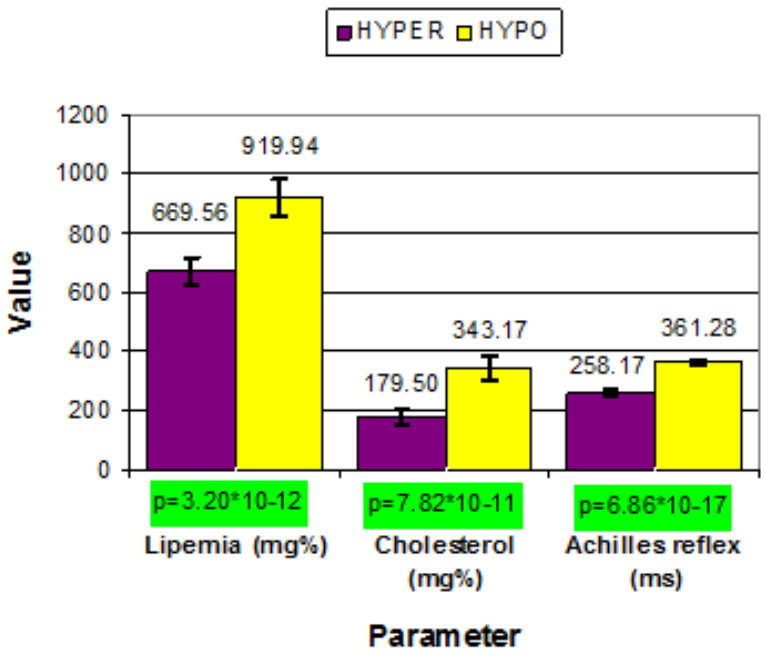

Fig.3. Above the superior part of any column is the absolute numerical value of the parameter. The small horizontal rectangles, colored green, blue or yellow, placed below the abscise expose the $p$ values obtained through Student's t test, respectively how large the statistical ensurance of differences between the 2 patient lots is

with $p$ values between $p=5.8 \times 10^{-11}$ and $p=6.64 \times 10^{-20}$ ) (table 7 and 8 ).

In figure 2, 3 and 4 the differences of the average absolute values between the 2 groups (fig. 2, 3 ) and relative values \% (fig.4) can be seen.

Following these measurements, there was also a great mathematical correlation coefficient $r$ between the majority (9) of studied parameters [42, 45] (except for blood pressures), with values over 0.9 (0.902 to 0.986), correlations calculated by the Pearson formula $[43,44]$. That shows that if a parameter increases with $100 \%$, the other one for which the correlation was calculated to the first one modifies (plus or minus) with $90.2 \%$ respectively $98.61 \%$, which is an interesting scientific fact (table 9).

This precise mathematical determination of the thyroid function on the 2 groups was necessary to know exactly what thyroid pathology, how severe, we explore through VEP.

\section{Modifications of visual evoked potentials}

Tables 10 and 11 show that in hypothyroid patients the latency of the P100 increases by $17.88 \%(p<0.01)$, and the one of the N75 wave only with $9.88 \%(p<0.05)$, as proved by the Student's t test, but also by the Mann-Witney and ANOVA tests (table 10).
Relative values of hormonal, biochemical, paraclinical and phy siological determin ations on hypothy roid patients in percentages, compared to hyperthy roid patients (100\%) एHYPO - $-\mathrm{HYPER}$

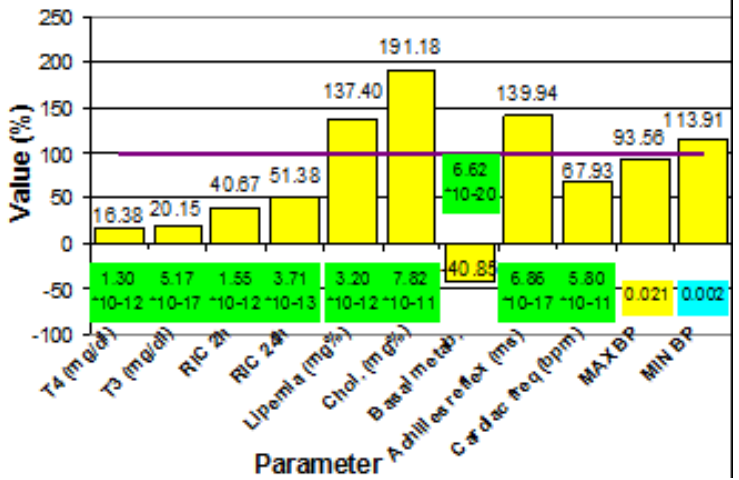

Fig.4. Above the superior part of any column is the absolute numerical value of the parameter. The small horizontal rectangles, colored green, blue or yellow, placed below the abscise expose the $p$ values obtained through Student's $t$ test, respectively how

large the statistical ensurance of differences between the 2 patient lots is

Also, the duration of the N75 wave drops with $26.37 \%$ ( $p$ $=0.0265$ ). All these differences of the VEP waves, statistically significant or not, are presented \% in figure 5

In addition to the quoted authors we found important percentage differences, highly significant $(p<0.001)$ for P100 and only significant $(p<0.05)$ for N75, because we had greater differences of the thyroid function between hyper and hypothyroid patients, while all previously quoted article showed smaller differences between normal thyroid and hypothyroid patients (in most articles) or between normal thyroid and hyperthyroid patients. Moreover, some authors note statistically significant differences, others don't, but no information is given on the severity of thyroid pathology. Possibly the pathology was more severe for some authors, and easier for others, where the increase of the latency of the P100 wave was not statistically significant.

The other parameters of the VEP, other than N75 and P100 waves, although presenting great percentage differences, up to $52.35 \%$, due to the high dispersion of the individual values obtained on them (with CV\% between 25.17 and $151.16 \%$, the majority around $80 \%$ ), showed no statistic significant differences - as observed more clearly in table 11 and figure 5 .

In order to interpret all the differences of the average values of all VEP parameters on the two main waves N75 and P100, even if they are not statistically significant (beside latency differences), we must start, in order to interpret

Table 9

CORRELATION COEFFICIENTS R OBTAINED WITH THE PEARSON FORMULA BETWEEN ALL AVERAGE VALUES OF PREVIOUSLY MENTIONED PARAMETERS. VERY HIGH SIGNIFICANT CORRELATIONS BETWEEN MOST OF THE BIOCHEMICAL, HORMONAL AND PARACLINIC PARAMETERS (EXCEPT BLOOD PRESSURE)

\begin{tabular}{|l|l|l|l|l|l|l|l|}
\hline & $\begin{array}{l}\text { T4 } \\
\text { (mg/dl) }\end{array}$ & $\begin{array}{l}\text { Lipemia } \\
(\mathbf{m g} \%)\end{array}$ & $\begin{array}{l}\text { Chol. } \\
(\mathbf{m g} \%)\end{array}$ & $\begin{array}{l}\text { Achilles } \\
\text { Reflex } \\
(\mathbf{m s})\end{array}$ & $\begin{array}{l}\text { Cardiac } \\
\text { Freq. } \\
(\mathbf{b p m})\end{array}$ & $\begin{array}{l}\text { MAX BP } \\
\text { (mmHg) }\end{array}$ & $\begin{array}{l}\text { MIN BP } \\
\text { (mmHg) }\end{array}$ \\
\hline T3 (mg/dl) & 0.985 & -0.922 & -0.936 & -0.989 & 0.962 & 0.351 & -0.511 \\
\hline T4 (mg/dl) & & -0.906 & -0.914 & -0.969 & 0.961 & 0.397 & -0.495 \\
\hline Lipemia (mg\%) & & & 0.979 & 0.902 & -0.908 & -0.446 & 0.361 \\
\hline Cholesterol (mg\%) & & & & 0.918 & -0.918 & -0.393 & 0.413 \\
\hline Achilles Reflex (ms) & & & & & -0.947 & -0.383 & 0.500 \\
\hline Frequency (bpm) & & & & & & 0.346 & -0.524 \\
\hline MAX BP (mmHg) & & & & & & & 0.449 \\
\hline
\end{tabular}


Table10

AVERAGES, STANDARD DEVIATIONS, CV\%, STANDARD ERRORS IN HYPOTHYROID PATIENTS AS OPPOSED TO HYPERTHYROID PATIENTS FOR THE IMPORTANT PARAMETERS OF THE VEP WAVES (N75, P100). DIFFERENCES AND STATISTICAL INSURANCES OF DIFFENCES. HERE WE FIND LESS STATISTICAL ENSURED DIFFERENCES, AND NONE IS VERY HIGH SIGNIFICANT

\begin{tabular}{|c|c|c|c|c|c|c|c|c|c|c|c|c|c|}
\hline & \multicolumn{4}{|c|}{ HYPERTHYROID PATIENTS } & \multicolumn{4}{|c|}{ HYPOTHYROID PATIENTS } & \multicolumn{2}{|c|}{ Difference } & \multicolumn{3}{|c|}{ Statistical ensurence by: } \\
\hline & Mean & StdDev & C.V.\% & StdErr & Mean & StdDev & C.V.\% & StdErr & Abs. & Rel.\% & Student & Mann & Anova \\
\hline $\begin{array}{l}\text { Latency } \\
\mathrm{N}_{75} \text { wave }\end{array}$ & 68.97 & 4.49 & 6.51 & 1.5 & 75.85 & 6.81 & 8.98 & 1.97 & 6.88 & 9.98 & 0.0166 & $\mathrm{~s}$ & 0.0159 \\
\hline $\begin{array}{l}\text { Latency } \\
\mathrm{P}_{100} \text { wave }\end{array}$ & 83.88 & 12.8 & 15.26 & 4.27 & 98.88 & 6.04 & 6.11 & 1.82 & 15 & 17.88 & 0.0028 & HS & 0.0031 \\
\hline $\begin{array}{l}\text { Amplitude } \\
\mathrm{N}_{75} \text { wave }\end{array}$ & 1.95 & 1.01 & 51.79 & 0.36 & 1.71 & 1.59 & 92.98 & 0.48 & -0.24 & -12.31 & 0.74 & NS & 0.72 \\
\hline $\begin{array}{l}\text { Amplitude } \\
\mathrm{P}_{100} \text { wave }\end{array}$ & 4.18 & 2.28 & 54.55 & 0.76 & 4.91 & 3.46 & 70.47 & 1.04 & 0.73 & 17.46 & 0.61 & NS & 0.59 \\
\hline $\begin{array}{l}\text { Duration } \\
\mathrm{N}_{75} \text { wave }\end{array}$ & 22.45 & 6.02 & 26.82 & 1.74 & 16.53 & 6.81 & 41.20 & 1.76 & -5.92 & -26.37 & 0.0265 & s & 0.025 \\
\hline $\begin{array}{l}\text { Duration } \\
\mathrm{P}_{100} \text { wave }\end{array}$ & 34.41 & 8.66 & 25.17 & 3.06 & 27.59 & 10.47 & 37.95 & 2.7 & -6.82 & -19.82 & 0.15 & NS & 0.1277 \\
\hline $\begin{array}{l}\text { Steepness } \\
\mathrm{N}_{75} \text { wave }\end{array}$ & 0.25 & 0.12 & 48.00 & 0.04 & 0.19 & 0.1 & 52.63 & 0.03 & -0.06 & -24.00 & 0.25 & NS & 0.2241 \\
\hline $\begin{array}{l}\text { Steaepness } \\
\mathrm{P}_{100} \text { wave }\end{array}$ & 0.28 & 0.21 & 75.00 & 0.07 & 0.32 & 0.21 & 65.63 & 0.04 & 0.04 & 14.29 & 0.65 & NS & 0.6482 \\
\hline Area $\mathrm{N}_{75}$ wave & 31.71 & 29.04 & 91.58 & 10.27 & 17.63 & 22.5 & 127.62 & 7.11 & -14.08 & -44.40 & 0.29 & NS & 0.2663 \\
\hline Area $P_{100}$ wave & 95.51 & 51.31 & 53.72 & 18.14 & 107.51 & 91.9 & 85.48 & 29.06 & 12 & 12.56 & 0.76 & NS & 0.7411 \\
\hline IBA $N_{75}$ wave & 0.79 & 0.85 & 107.59 & 0.3 & 0.43 & 0.65 & 151.16 & 0.21 & -0.36 & -45.57 & 0.36 & NS & 0.53 \\
\hline IBA $P_{1 c 0}$ wave & 1.49 & 1.4 & 93.96 & 0.49 & 2.27 & 2.6 & 114.54 & 0.82 & 0.78 & 52.35 & 0.41 & NS & 0.5345 \\
\hline LAI $\mathrm{N}_{75}$ wave & 35.36 & & & & 44.35 & & & & 8.98 & 25.41 & & & \\
\hline LAl $P_{100}$ wave & 20.06 & & & & 20.13 & & & & 0.071 & 0.35 & & & \\
\hline
\end{tabular}

Table 11

ABSOLUTE AND RELATIVE VALUES AND DIFFERENCES OF VEP PARAMETERS BETWEEN THE 2 LOTS OF THYROID PATIENTS AND THEIR STATISTICAL INSURANCES

\begin{tabular}{|c|c|c|c|c|c|c|c|c|c|c|c|c|c|c|}
\hline & $\begin{array}{l}\text { Latency } \\
\text { N75 }\end{array}$ & $\begin{array}{l}\text { Amplit } \\
\text { N75 }\end{array}$ & $\begin{array}{l}\text { Duration } \\
\text { N75 }\end{array}$ & $\begin{array}{l}\text { Steep } \\
\text { N75 }\end{array}$ & $\begin{array}{l}\text { Area } \\
\text { N75 }\end{array}$ & $\begin{array}{l}\text { IBA } \\
\text { N75 } \\
\end{array}$ & $\begin{array}{l}\text { LAl } \\
\text { N75 }\end{array}$ & $\begin{array}{l}\text { Latency } \\
\text { P100 }\end{array}$ & $\begin{array}{l}\text { Amplit. } \\
\text { P100 }\end{array}$ & $\begin{array}{l}\text { Duration } \\
\text { P100 }\end{array}$ & $\begin{array}{l}\text { Steep } \\
\text { P100 }\end{array}$ & $\begin{array}{l}\text { Area } \\
\text { P100 }\end{array}$ & $\begin{array}{l}\text { IBA } \\
\text { P100 }\end{array}$ & $\begin{array}{l}\text { LAI } \\
\text { P100 }\end{array}$ \\
\hline HIPER & 100.00 & 100.00 & 100.00 & 100.00 & 100.00 & 100.00 & 100.00 & 100.00 & 100.00 & 100.00 & 100.00 & 100.00 & 100.00 & 100.00 \\
\hline HIPO & 109.98 & 87.69 & 73.63 & 76.00 & 55.60 & 54.43 & 125.41 & 117.88 & 117.46 & 80.18 & 114.29 & 112.56 & 152.35 & 100.36 \\
\hline DIF. & -9.98 & 1231 & 26.37 & 24.00 & 44.40 & 45.57 & -25.41 & -17.88 & -17.46 & 19.82 & -14.29 & -1256 & -5235 & -0.36 \\
\hline p Stud & 0.0166 & 0.7400 & 0.0265 & 0.2500 & 0.2900 & 0.3600 & & 0.0028 & 0.6100 & 0.1500 & 0.6500 & 0.7600 & 0.4100 & \\
\hline
\end{tabular}

Relative values of electrophy silolo gical dete rminations (VEP pa rameters) on thy rold patients. Hy perthy rold patients are $100 \%$ (standard loth. p values Indicate the statistical in surance of the sald parameter between hy per and hypothy rold patle nts. एHYPO -HYPER

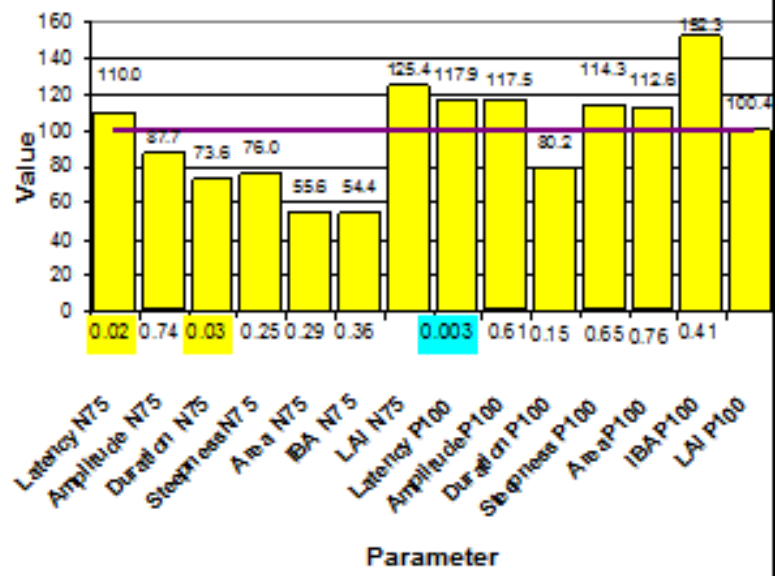

Fig.5. Above the superior part of any column is the absolute numerical value of the parameter. The small horizontal colored rectangles, blue or yellow, placed below the abscise expose the $p$ values obtained through Student's t test, respectively how large the statistical ensurance of differences between the 2 patient lots is

\section{Table 12}

TABLE OF RATIOS OF VEP, $\mathrm{P}_{10} / \mathrm{N}_{75}$, WAVES FOR AMPLITUDES AND SURFACES AND THE PERCENTAGE DIFFERENCES OF THE RATIOS BETWEEN HYPO AND HYPERTHYROID PATIENTS

\begin{tabular}{|l|l|l|l|}
\hline & $\begin{array}{l}\mathrm{P}_{100} / \mathrm{N}_{75} \text { ratios for } \\
\text { hyperthyroid } \\
\text { patients }\end{array}$ & $\begin{array}{l}\mathrm{P}_{100} / \mathrm{N}_{75} \text { ratios for } \\
\text { hypothyroid patients }\end{array}$ & $\begin{array}{l}\text { Differences \% between hypo and } \\
\text { hyperthyroid } \\
100 \%)\end{array}$ \\
\hline Amplitude $\mathrm{P}_{100} / \mathrm{N}_{75}$ & 2.1435997 & 2.871345 & $133.9497 \%$ \\
\hline Surface $\mathrm{P}_{100} / \mathrm{N}_{75}$ & 3.0081884 & 6.0981281 & $202.71759 \%$ \\
\hline
\end{tabular}


Table 13

CORRELATION COEFFICIENTS R BETWEEN THE MAIN ELECTROPHYSIOLOGICAL, HORMONAL AND PARACLINICAL PARAMETERS. THERE ARE WEAK STATISTICAL CORRELATIONS BETWEEN SOME VEP PARAMETERS AND BIOCHEMICAL, HORMONAL AND PARACLINIC PARAMETERS

\begin{tabular}{|l|l|l|l|l|l|l|}
\hline & \multicolumn{1}{|c|}{ T4 } & \multicolumn{1}{|c|}{ T3 } & \multicolumn{1}{|c|}{ Achilles Reflex } & \multicolumn{1}{|c|}{ Cardiac Freq. } & MAX BP & MIN BP \\
\hline Latency $\mathrm{N}_{75}$ wave & -0.222 & -0.27 & 0.344 & -0.288 & -0.442 & 0.263 \\
\hline Latency $\mathrm{P}_{100}$ wave & -0.143 & -0.103 & 0.2 & -0.024 & -0.546 & 0.121 \\
\hline Duration $\mathrm{N}_{75}$ wave & -0.671 & -0.669 & 0.603 & -0.661 & 0.566 & 0.66 \\
\hline Duration $\mathrm{P}_{100}$ wave & 0.097 & 0.198 & -0.206 & 0.168 & -0.402 & -0.23 \\
\hline Amplitude $\mathrm{N}_{75}$ wave & -0.211 & -0.204 & 0.193 & -0.226 & -0.08 & 0.064 \\
\hline Amplitude $\mathrm{P}_{100}$ wave & 0.082 & 0.069 & -0.071 & -0.056 & 0.153 & 0.095 \\
\hline
\end{tabular}

them, from the following safe scientific hypothesis: wave N75 is a VEP wave that expresses the excitation of the primary visual cortex generated by the sumation of the synaptic potentials, depolarized (negative), excitations generated by the synapses of the visual ways on the cortical neurons in field 17, while the VEP P100 wave appears by summing up hyper-polarizing inhibitory synapses (positive) produced by inhibitory synapses that come from satellite, inhibitory, cortical neurons, which, through their action, restrain chaotic, generalized spread of the excitation, limiting it only to the area on which it must command it, in which precise cortical processing of visual information are produced.

Latencies increase because, in hypothyroid patients, all neuronal processes, including excitation (especially through synapses), are delayed.

As soon as the latency of the N75 wave increases, the latency of the P100 wave, that is triggered by the N75 wave, forcibly increases higher and better statistically ensured, because the synaptic transmission between excited neurons (wave N75) and inhibitory satellite ones, as well as the transmission between recurrent fibers of inhibitory satellite neurons that come back on exciting neurons are also extended in time. It is precisely explained that the latency of the N75 wave increases only by $9.98 \%$ (weak statistical significance, close to 0,05), while the one of the P100 wave increases almost double, up to $17.88 \%$ - highly significant $(p<0.001)$.

Finally, it is observed that all parameters expressing energy, the action power of a wave (the amplitude, duration, area, steepness and IBA) decrease a lot for N75 and increase (although inhibition increases) for P100, even up to 12 or $17.52 \%$ (fig. 5).

In order to have a precise synthetic, numerical information of the balance between excitation and inhibition we realized the ratio between P100/N75 amplitude in hyperthyroid (2.1435) and hypothyroids (2.8713) patients. Therefore, the balance leaned towards inhibition with 33.94\% (in favor of inhibition); in hypothyroid patients the same ratios, but for P100/N75 areas, are much higher (3.008 as opposed to 6.098), thus a predomination of inhibition with $108.71 \%$ in hypothyroid patients, double compared to hyperthyroid patients $(6.098$, and 3.008 respectively) (table 12).

Correlations between the parameters of VEP waves and laboratory determinations ${ }^{*} T 3, T 4, R I C$, Lipemia etc.). Weak correlations were obtained only between the duration of the N75 wave and all the other 7 non-electrophysiological obtained parameters (Table 13).

The wave duration, on which the surface (energy, power) of the N75 wave depends, shows that it modifies unitarily with the 7 parameters and that these hormonal, humoral, preclinical modifications have an influence on some VEP parameters (duration especially) [22].
It is noticeable that, in all researched literature regarding VEP modifications induced by thyroid pathology, no safe statistical researches are performed through several formulas, nothing is said about the severity of the pathology mirrored in several hormonal, biochemical and paraclinical analyses, and VEP [4]. No correlation calculus is performed between all non-electrophysiological parameters and some electrophysiological parameters - statistical processing that brought a safe base to the existence of a liason of the severity of thyroid pathology with VEP modifications[26].

Plus, all global clinical and VEP researches, in all literature, with no exception, have only followed or shown modifications of the latency of the P100 wave, sometimes of the amplitude and very rarely of the duration [17]. Nothing about the other important waves of VEP (N75 and N135), and measure of all their parameters (latency, amplitude, duration, surface, steepness of wave increase). New, original indices proposed by us, IBA = steepness $x$ amplitude index and $\mathrm{LAI}=$ latency/amplitude index, weren't even experimentally determined in literature [25]. Whereas its impossible to make a statement about the balance between excitation (represented by N75) and inhibition (represented by P100), about the mathematic ratio between them and its modification according to thyroid pathology [19].

\section{Conclusions}

Following the recording of visual evoked potentials and of 11 humoral and paraclinical parameters on two thyroid patients groups (18hyperthyroid, 18 hypothyroid), the result were:

The age of the illness and treatment duration are much higher in hypothyroid patients (highly significant differences, $p<0.01$ ).

The 11 humoral and paraclinical determined parameters, in their majority, have very different values between the 2 groups, with statistically significant differences $(p<0.001)$.

Seven humoral and paraclinical parameters correlate extremely well with each other, (Pearson's r correlation coefficients over 0.9 ) showing that they modify in parallel with the level of thyroid activity.

The latency of the N75 wave is significantly increased, and the one of the P100 wave is significantly high in hypothyroid patients, with $9.98 \%$, and $17.88 \%$ respectively.

The duration of the N75 wave is significantly lower, with statistical significance, in hypothyroid patients, by $26.37 \%$. Short duration = little energy, reduced excitation.

The duration of the N75 wave correlates with most humoral and paraclinical parameters.

The ratios of the amplitudes and of the areas of the P100/ N75 wave indicate a precisely quantified higher predominance of the inhibition in the visual cortex in hypothyroid patients. 


\section{References}

1.GAMAN, A., TAISESCU, C.I. Aplastic Anemia During Antithyroid Drugs in Hyperthyroidism. Revista Acta Endocrinologica (Buc) 2008, 4 (4) pag :465-470

2.*** American Clinical Neurophysiology Society. Recommended standards for short-latency auditory evoked potentials Guideline 9C: Guidelines on Short-Latency Auditory Evoked Potentials. Journal of Clinical Neurophysiology. 2006;23(2):157-67.

3.ANJ ANA, Y., VANEY, N., TANDON, O.P., MADHU, S.V. Functional status of auditory pathways in hypothyroidism: evoked potential study. Indian J Physiol Pharmacol. 2006;50(4):341-49.

4.BOETTCHER, F.A. Presbyacusis and the auditory brainstem response. J Speech Lang Hear Res. 2002;45(6):1249-61.

5.CHIAPPA, K.A. Principles of evoked potentials. 3rd ed. Philadelphia: Lippincott Raven Publishers; 1997. pp. 01-30.

6.BERBECE, S.I., CONDRATOVICI PLESEA, A., PAVEL, L.L., GRIGORE, A.C., Rev. Chim. (Bucharest), 68, no. 5, 2017, p. 1075-1076

7.DAIANU, O., GEORGESCU, A.M., CIUREA, M.E. et al. Temozolomide and targeted therapy against epidermal growth factor receptor in glioma. Int J Clin Exp Med 2016;9(8):15249-15261

8.DI LORENZO, L., FOGGIA, L., PANZA, N., CALABRESE, M.R., MOTTA, G., TRACHINO, G., et al. Auditory brainstem responses in thyroid diseases before and after therapy. Horm Res. 1995;43(5):200-05.

9.FIGUEIREDO, L.C., LIMA, M.C., VAISMAN M. Changes in audiometry brainstem response in adult women with subclinical hypothyroidism. Rev Bras Otorrinolaringol. 2003;69:542-47.

10.FUSARU, A.M., PISOSCHI, C.G., BOLD, A., TAISESCU, C.I. et al. Hypoxia induced VEGF synthesis in visceral adipose depots of obese diabetic patients. Rom J Morphol Embryol 2012, 53(4):903-909

11.GARG, A., VANDERPUMP, M.P.J. Subclinical thyroid disease. Br Med Bull. 2013;107(1):101-16.

12.BERCEANU, C., PAITICI, S., BERCEANU, S., BRATILA, E., OFITERU, A.M., MEHEDINTU, C., BERBECE, S.I., NAVOLAN, D., OBLEAGA, C.V., BALSEANU, A.T., Rev. Chim. (Bucharest), 69, no. 8, 2018, p. 22452250.

13.J ACKSON, I.M., RENFREW, S. The diagnostic value of the EEG in thyrotoxicosis. Acta Endocrinol (Copenh) 1966 Jul;52(3):399-403.

14.JAYANTHI, M., VINODHA, R. Prolongation of interpeak latency of brainstem auditory evoked potential in hypothyroidism. Int J Med Res Health Sci. 2016;5(3):22-27.

15.KNIPPER, M., BANDTLOW, C., GESTWA, L., KOPSCHALL, I., ROHBOCK, K., WIECHERS, B., etal. Thyroid hormone affects Schwann cell and oligodendrocyte gene expression at the glial transition zone of the VIIIth nerve prior to cochlea function. Development. 1998;125(18):3709-18.

16.BERCEANU, C., CIUREA, E.L., CIRSTOIU, M.M., BERCEANU, S., OFITERU, A.M., MEHEDINTU, C., BERBECE, S.I., CIORTEA, R., STEPAN, A.E., BALSEANU, A.T., Rev. Chim. (Bucharest), 69, no. 9, 2018, p. 2396-2401

17.KOWSALYA, V., VIJAYAKUMAR, R., CHANDRASEKHAR, M. Electrophysiological changes on brainstem auditory evoked potentials in hypothyroid patients. International Journal of Basic and Applied Medical Sciences. 2014;4(1):29-37.

18.LADENSON, P.W., STAKES, J.W., RIDGWAY, E.C. Reversible alteration of the visual evoked potential in hypothyroidism. Am J Med. 1984 Dec;77(6):1010-1014.

19.LAI, C.L., TAI, C.T., LIU, R.T., HOWNG, S.L. A longitudinal study of central and peripheral nerve conduction in hypothyroid rats. J Neurol Sci. 1997;148(2):139-45.

20.MASTAGLIA, F.L., BLACK, J.L., COLLINS, D.W., GUTTERIDGE, D.H., YUEN, R.W. Slowing of conduction in visual pathway in hypothyroidism. Lancet. 1978 Feb 18;1(8060):387-388.

21.JECAN, C.R., NICOLAU, A., FLORESCU, I.P., ARDELEANU, V., BERBECE, S., Mat.Plast., 54, no. 1, 2017, p. 88-90.

22.NISHITANI, H., KOOI, K.A. Cerebral evoked responses in hypothyroidism. Electroencephalogr Clin Neurophysiol. 1968 Jun;24(6):554-560
23.OZATA, M., OZKARDES A., CORAKCI, A., GUNDOGAN, M.A. Subclinical hypothyroidism does not lead to alterations either in peripheral nerves or in brainstem auditory evoked potentials (BAEPS) Thyroid. 1995;5(3):201-05.

24.ARDELEANU, V., BERBECE, S.I., FLORESCU, I.P., JECAN, C.R., Mat. plast., 54, no. 1, 2017, p. 37-40

25.OZATA, M., OZKARDES A., GUNDOGAN, M.A. Effects of acute hypothyroidism on brainstem auditory evoked potentials. Tr. J ournal of Medical Sciences. 1998;28:133-37.

26.PARLE, J.V., FRANKLYN, J.A., CROSS, K.W., J ONES, S.C., SHEPPARD, M.C. Prevalence and follow-up of abnormal thyrotrophin (TSH) concentrations in the elderly in the United Kingdom. Clin Endocrinol (Oxf) 1991;34(1):77-83.

27.FILIP, I.C., BERBECE, S., RADUCU, L., FLORESCU, I.P., ARDELEANU, V., JECAN, C.R., Mat. Plast., 54, no. 3, 2017, p. 414-417

28.PETRESCU, I.O., BICIUSCA V, TAISESCU, C.I. et al. Histological factors that predict the liver fibrosis in patients with chronic hepatitis C. Rom J Morphol Embryol 2016, 57(2 Suppl):759-765.

29.BERBECE, S., ILIESCU, D., ARDELEANU, V., NICOLAU, A., JECAN, C.R. Rev. Chim. (Bucharest), 68, no. 7, 2017, p. 1438-1441

30.ROSS, D.S. Serum thyroid-stimulating hormone measurement for assessment of thyroid function and disease. Endocrinol Metab Clin North Am. 2001;30:245-64.

31.CIOBOTARU, O.C., CIOBOTARU, O.R., VOICU, D.C., BARNA, O., BARNA, I.,VOINESCU, D.C., Biotechnol Biotechnol Equip, 30:2, 341345

32.SCHORTGEN, F., GIROU, E., DEYE, N., BROCHARD, L.; Cryco Study Group. Do hypooncotic fluids for shock increase the risk of lateonset acute respiratory distress syndrome? Intensive Care Med. 2010 Oct:36(10):1724-34.

33.SHARMA, K., BEHERA, J.K., KUMAR, N., SOOD, S., MADAN, H.S., DAS S. Brainstem evoked potential in newly diagnosed patients of subclinical hypothyroidism. N Am J Med Sci. 2015;7(4):131-34.

34.CIUBARA, A.B., TUDOR, R.C., NECHITA, L., TITA, O., CIUBARA, A., TURLIUC, S., RAFTU, G., Rev. chimie (Bucharest), 69, no. 5, 2018, p. 1250

35.SHARMA, K., KUMAR, N., BEHERA, J.K., SOOD, S., DAS, S., MADAN, H.S. Brainstem auditory evoked potential in clinical hypothyroidism. AvicennaJ Med. 2015;5(3):79-82.

36.SURKS, M.I., ORTIZ, E., DANIELS, G.H., SAWIN, C.T., COL, N.F., COBIN, R.H., et al. Subclinical thyroid disease: scientific review and guidelines for diagnosis and management. JAMA. 2004;291(2):228-38. 37.TAISESCU, C.I., ILIESCU, G., TAISESCU, O., et al. Hematological adverse effects of interferon and ribavirin treatment in patients with chronic C virus hepatitis. Farmacia, 2015; 63 (3): 465-469

38.CIOBOTARU, O.R., VOINESCU, D.C., BARNA, O., BARNA, I., CIOBOTARU, O.C., Biotechnol Biotechnol Equip, 29:5, 935-941

39.TAKAHASHI, K., FUJ ITANI, Y. Somatosensory and visual evoked potentials in hyperthyroidism. Electroencephalogr Clin Neurophysiol. 1970 Dec;29(6):551-556.

40.UNNIKRISHNAN, A.G., KALRA, S., SAHAY, R.K., BATWAL, G., JOHN, M., TEWERI, N.. Prevalence of hypothyroidism in adults: an epidemiological study in eight cities of India. Indian J Endocrinol Metab. 2013;17(4):647-52.

41.US Preventive Services Task Force. Screening for thyroid disease: recommendation statement. Ann Intern Med. 2004;140(2):125-27.

42.VANASSE, M., FISCHER, C., BERTHEZENE, F., ROUX, Y., VOLMAN, G., MORNEX, R. Normal brainstem auditory evoked potentials in adult hypothyroidism. Laryngoscope. 1989;99(3):302-06.

43.CIUBARA, A.B., NECHITA, A., TUDOR, R.C., MATEI, N.M., TUTUNARU, D., SIRBU, P.D., Rev. de cercetare si interventie sociala, 2018, vol 60, p. $174-179$

44.CIOBOTARIU, O.R., BRIA, V., GRAUR, I., VOINESCU, D.C., Rev. Chim. (Bucharest), 66, no. 11, 2015, p. 1903-1906

45.VANDERPUMP, M.P. The epidemiology of thyroid disease. Br Med Bull. 2011;99:39-51.

$\overline{\text { Manuscript received: } 14.02 .2019}$ 